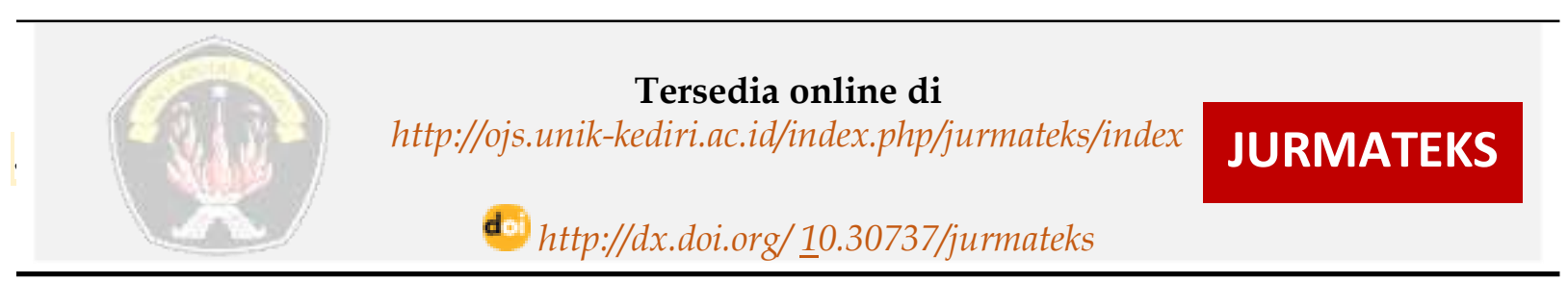

\title{
Analisis Penerapan Keselamatan Dan Kesehatan Kerja (K3) Pembangunan Gedung Kuliah Bersama Kampus C Unair Surabaya
}

\author{
Y. Saraswati ${ }^{1 *}$, A. Ridwan ${ }^{2}$, A. I. Candra ${ }^{3}$ \\ ${ }^{1 * 2,3}$ Fakultas Teknik, Universitas Kadiri \\ Email:1'yusiane@gmail.com.
}

\begin{tabular}{ll} 
A R T I C L E I N F O \\
\hline Article history: & \\
Artikel masuk & $: 22-09-2020$ \\
Artikel revisi & $: 25-09-2020$ \\
Artikel diterima & $: 28-09-2020$ \\
\hline
\end{tabular}

Keywords:

Occupational Health Safety, Statistical Frequency, Validity Test, Reliability Test

Style IEEE dalam mensitasi artikel ini:

[8]

M. Lesch, "Comprehension and Memory For Warning Symbols: Age Related Differences and Impact of Training," J. Safety Res., vol. 34, pp. 495-505, 2003

\begin{abstract}
A B S T R A C T
Implementation of multi storey building construction projects is very prone of work accidents, so the application of Occupational Safety and Health must be strictly considered. This study purposes are to determine the most dominant occupational safety and health implementation measures and the level of implementation of occupational safety and health in the Shared Lecture Building Project Of Campus $C$ Airlangga University Surabaya. This research uses quantitative descriptive method. The research populations are 150 workers, which include: security, workers, foremen, safety officer, project implementers and management staff. The sample was determined by the slovin technique with the results of 60 respondents. Data collection by distributing questionnaires to respondents. The results of data collection were tested for validity, realibility testing and statistical frequency analysts using IBM SPSS Statistics 25 software. In this study the most dominant results of the application of Occupational Safety and Health $(K 3)$ is checking the condition of PPE and the provision of PPE that is periodically complete with a value of 91.70\%. The application level of Occupational Safety and Health (K3) in the Shared Lecture Building Project Of Campus C Airlangga University Surabaya has a percentage of $77.84 \%$, so it can be classified in the VERY GOOD category.
\end{abstract}

\section{A B S T R A K}

Pelaksanaan proyek konstruksi gedung bertingkat sangat rawan akan terjadinya kecelakaan kerja, sehingga penerapan Keselamatan dan Kesehatan Kerja harus benar-benar diperhatikan. Tujuan dilakukan penelitian ini untuk mengetahui tindakan penerapan Keselamatan dan Kesehatan Kerja yang paling dominan dan tingkat penerapan Keselamatan dan Kesehatan Kerja pada proyek pembangunan Gedung Kuliah Bersama Kampus C UNAIR Surabaya. Metode penelitian ini menggunakan deskriptif kuantitatif. Populasi penelitian berjumlah 150 tenaga kerja yang meliputi: satpam, pekerja, mandor, pelaksana K3, pelaksana proyek dan staff manajemen. Sampel ditentukan dengan teknik slovin dengan hasil 60 responden. Pengumpulan data dengan membagikan kuisoner

Analisis Penerapan Keselamatan Dan Kesehatan Kerja (K3) Pembangunan Gedung Kuliah Bersama Kampus C Unair Surabaya 
kepada responden. Hasil pengumpulan data dilakukan uji validitas, uji reliabilitas dan analis frequensi statistic menggunakan software IBM SPSS Statistic 25. Pada penelitian ini di dapatkan hasil tindakan penerapan Keselamatan dan Kesehatan Kerja (K3) yang paling dominan adalah Pengecekan Kondisi APD dan Penyediaan APD yang lengkap secara berkala dengan nilai 91,70\%. Tingkat penerapan Keselamatan dan Kesehatan Kerja (K3) Pada Proyek Pembangunan Gedung Kuliah Bersama Kampus C UNAIR memiliki prosentase 77,84 $\%$, sehingga dapat di klasifikasikan dalam kategori SANGAT BAIK.

\section{Pendahuluan}

Kecelakaan kerja adalah suatu hal yang terjadi dengan tidak disengaja dan tidak dikehendaki yang menimbulkan kerugian ringan maupun fatal baik secara fisik, mental maupun material [1]. Seperti cedera ringan hingga cedera berat, cacat fisik, trauma, bahkan kematian. Semua pekerjaan memiliki resiko kecelakaan kerja, baik kecelakaan kerja di jalan menuju tempat kerja maupun kecelakaan kerja di lokasi pekerjaan. Salah satu pekerjaan yang memiliki resiko kecelakaan tertinggi adalah pekerjaan konstruksi, karena pekerjaan konstruksi berhubungan dengan alat berat, ketinggian, polusi udara dan kebisingan [2].

Hal ini tentu saja membutuhkan perhatian ekstra untuk mencegah resiko terjadinya kecelakaan kerja dan gangguan kesehatan yang ditimbulkan dari pekerjaan tersebut. Salah satu upaya pencegahan terjadinya kecelakaan kerja adalah dengan diterapkannya Keselamatan dan Kesehatan Kerja (K3) [3]. K3 merupakan segala kegiatan yang bertujuan untuk menjamin dan melindungi keselamatan dan kesehatan tenaga kerja melalui upaya pencegahan kecelakaan kerja dan penyakit akibat kerja. Tinggi nya angka kecelakaan kerja di Indonesia menunjukkan bahwa masih banyak pekerja yang mengabaikan masalah keselamatan dan kesehatan kerja (K3) [4] serta prosedur penerapannya karena lebih memilih untuk bekerja beradasarkan pengalaman [5].

Gedung Kuliah Bersama Kampus C UNAIR Surabaya memiliki ketinggian bangunan 12 lantai dengan jumlah pekerja yang terlibat sekitar 150 tenaga kerja mulai dari tukang, pekerja, mandor, satpam, pelaksana, dan staff manajemen. Proyek konstruksi yang sedang berlangsung di lingkungan kampus dirasa perlu perhatian lebih, karena proyek konstruksi berlangsung di tengah kegiatan perkuliahan dimana banyak mahasiswa, dosen dan staff yang beraktivitas di lingkungan kampus, mengingat proyek konstruksi pada umumnya rentan akan terjadinya kecelakaan kerja. Penerapan keselamatan dan kesehatan kerja yang baik dan benar sangat diperlukan untuk meminimalisir terjadinya kecelakaan kerja yang dapat menghambat berjalannya suatu proyek. Terutama proyek gedung bertingkat yang berlokasi di wilayah 
kampus dimana kegiatan belajar mengajar berlangsung. Hal itulah yang menjadi alasan bagi penulis untuk menganalisis tingkat penerapan Keselamatan dan Kesehatan Kerja pada proyek pembangunan Gedung Kuliah Bersama Kampus C UNAIR.

\section{Studi Literatur}

\subsection{Keselamatan dan Kesehatan Kerja}

Menurut OHSAS 18001:2007 Keselamatan dan Kesehatan Kerja (K3) adalah semua kondisi dan faktor yang dapat berdampak pada keselamatan dan kesehatan kerja tenaga kerja maupun orang lain (kontraktor, pemasok, pengunjung dan tamu) di tempat kerja[6]. Berdasarkan UU No. 1 Tahun 1970 Tentang Keselamatan Kerja, tujuan K3 adalah mencegah terjadinya kecelakaan dan sakit dikarenakan pekerjaan. Selain itu, K3 juga berfungsi untuk melindungi semua sumber produksi agar dapat digunakan secara efektif [7].

\subsection{Kecelakaan Kerja}

Kesuksesan suatu proyek dipengaruhi oleh berbagai faktor, salah satunya kecelakaan kerja di proyek konstruksi yang dapat menghambat kinerja dan tercapainya sasaran proyek [8].Kecelakaan kerja merupakan suatu kejadian yang merugikan yang tidak dikehendaki dan tidak di duga dan tidak ada unsur kesengajaan yang dapat menimbulkan korban jiwa dan harta benda [9].

\subsection{Penerapan K3 Pada Proyek Konstruksi}

Penerapan pelaksanaan keselamatan dan kesehatan kerja di lapangan seringkali diabaikan, pengecekan alat berat yang berpotensi menimbulkan bahaya secara berkala, prosedur pelaksanaan pekerjaan yang aman dan sesuai SOP, pemakaian APD sering tidak dilaksanakan dengan benar di lapangan [10]. Padahal jika diterapkan dengan benar, dapat meminimalisir kecelakaan kerja dan kerugian yang ditimbulkan [11].

\subsection{Alat Pelindung Diri (APD)}

Salah satu bagian penting dari pelaksanaan Keselamatan dan Kesehatan Kerja adalah APD (Alat Pelindung Diri) [8]. Penggunaan APD sering diabaikan oleh para pekerja karena kurangnya kesadaran akan pentingnya K3. Padahal penggunaan APD yang lengkap, dapat meminimalisir terjadinya cidera [12]. 


\subsection{Fasilitas Pengaman Proyek}

Disamping penggunaan APD, kelengkapan fasilitas pengaman proyek juga sangat diperlukan untuk meminimalisir terjadinya kecelakaan kerja, seperti: jaring pengaman, rambu-rambu. spanduk peringatan K3. hydrant. lampu peringatan. alarm peringatan, dll [13].

\subsection{Penelitian Terdahulu}

Berdasarkan penelitian yang dilakukan oleh Erni Kurniawati, et al (2018) dalam jurnal "KESELAMATAN DAN KESEHATAN KERJA (K3) PADA PROYEK KONSTRUKSI DI KOTA BANDUNG” yang dilakukan dengan metode kuantitatif dan teknik pengumpulan data dengan membagikan kuesioner didapatkan hasil bahwa kendala dalam menerapkan K3 terdapat pada sisi pekerja, hal ini terjadi karena kurangnya pengetahuan pekerja tentang K3[14]. Jadi dapat disimpulkan bahwa pengetahuan pekerja tentang $\mathrm{K} 3$ berperan besar dalam penerapan pelaksanaan $\mathrm{K} 3$, hal itulah yang mendasari peneliti untuk menambahkan pernyataan dalam kuesioner yang berkaitan dengan pemahaman pekerja mengenai $\mathrm{K} 3$.

\section{Metodologi Penelitian}

Metode yang digunakan dalam penelitian ini adalah metode deskriptif kuantitatif yaitu dengan metode observasi, variable, populasi, sampel, instrument penelitian, pengumpulan data, dan analis data [15].

\subsection{Populasi}

Populasi adalah sebagai wilayah generalisasi yang terdiri atas obyek dan subyek yang mempunyai kualitas dan karakteristik tertentu yang ditetapkan oleh peneliti untuk dipelajari dan kemudian ditarik kesimpulannya[16]. Populasi dalam penelitian ini adalah semua karyawan/pekerja yang terlibat dalam proyek Pembangunan Gedung Kuliah Bersama Kampus C UNAIR Surabaya yang dikerjakan oleh PT SASMITO berjumlah kurang lebih 150 orang. Meliputi Satpam, Mandor, Tukang, Pekerja, Staff Teknik, Staff K3 dan Staff Manajemen.

\subsection{Sampel}

Sampel merupakan bagian dari jumlah dan karakteristik yang dimiliki oleh populasi tersebut[17]. Sampel dalam penelitian ini meliputi tukang, pekerja, mandor, pelaksana K3, pelaksana proyek dan staff manajemen yang bekerja di proyek pembangunan Gedung Kuliah. 
Bersama Kampus C UNAIR Surabaya. Dalam penelitian ini penulis menentukan jumlah sampel menggunakan teknik Slovin [18].

$$
\begin{aligned}
& n=\frac{N}{1+\left(N e^{2}\right)} \\
& n=\frac{150}{1+\left(150 \times 0,1^{2}\right)}=\frac{150}{1,50+1}=60
\end{aligned}
$$

Berdasarkan hasil perhitungan di atas maka disimpulkan jumlah sampel dalam penelitian ini adalah 60 sampel.

\section{Keterangan:}

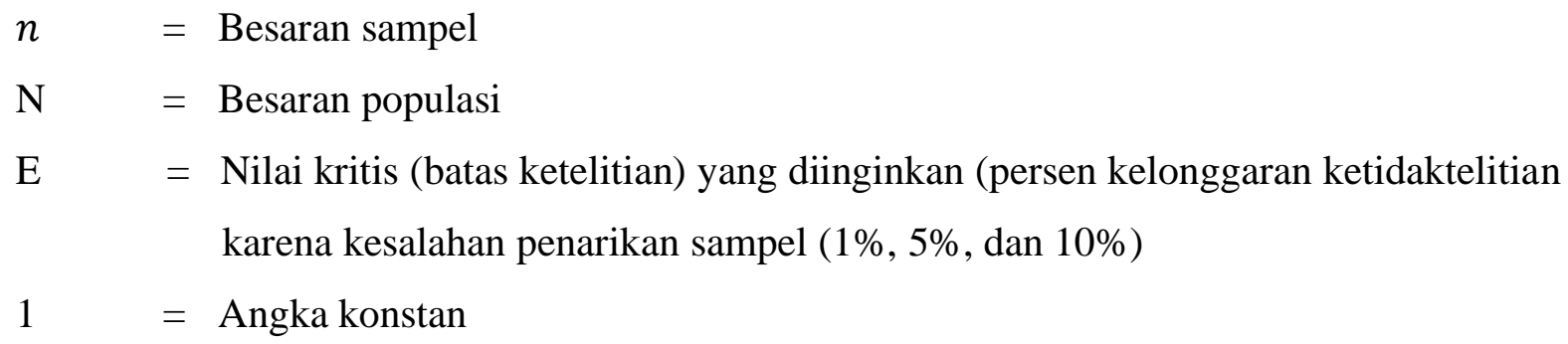

\subsection{Tahap Pengumpulan Data}

Metode pengumpulan data yang digunakan dalam penelitian ini menggunakan kuesioner. Kuesioner adalah daftar pertanyaan-pertanyaan tertulis yang diisi oleh responden yang bertujuan untuk mengumpulkan informasi yang dibutuhkan oleh peneliti. Kuesioner yang digunakan oleh peneliti berbentuk check list. Check list merupakan sebuah daftar variabel yang berupa pernyataan dimana responden akan memberikan tanda centang pada setiap permunculan gejala yang dimaksud.

\subsection{Instrumen Penelitian}

Meneliti berarti melakukan pengukuran terhadap suatu fenomena [17]. Dapat ditarik kesimpulan bahwa kita memerlukan tolak ukur dalam melakukan pengukuran yaitu instrumen penelitian. Instrumen penelitian adalah alat yang digunakan untuk mengukur fenomena yang di amati [19]. Jadi instrumen yang digunakan dalam penelitian ini adalah kuesioner yang diisi oleh responden untuk kemudian diolah menggunakan software. Pada penelitian ini penulis menggunakan software IBM SPSS Statistic 25. Software ini akan digunakan oleh penulis untuk melakukan uji validitas, uji reliabilitas dan uji analisis frekuensi statistik. 


\subsubsection{Uji Validitas}

Uji validitas digunakan untuk mengukur valid tidaknya suatu kuesioner [20]. Uji validitas instrumen pada penelitian ini menggunakan rumus Pearson Product Moment sebagai berikut [21]:

$R_{x y}=\frac{N \sum X Y-\left(\sum X\right)\left(\sum Y\right)}{\sqrt{\left\{N \sum X^{2}-\left(\sum X^{2}\right)\right\}\left\{N \sum Y^{2}-\left(\sum Y\right)^{2}\right\}}}$

Keterangan:

Rxy = Koefisien korelasi butir

$\sum \mathrm{Y}=$ Jumlah skor total butir dari keseluruhan responden

$\sum \mathrm{X}=$ Jumlah skor tiap butir

$\mathrm{N}=$ Jumlah Sampel

Valid atau tidak nya suatu instrumen penelitian dapat diketahui dari nilai $r$ hitung, jika nilai rhitung > rtabel maka instrumen tersebut dianggap valid.

\subsubsection{Uji Reliabilitas}

Uji reliabilitas bertujuan mengetahui konsistensi hasil pengukuran. Jika hasilnya konsisten, maka instrumen tersebut dapat dipercaya. Pada penelitian ini, digunakan metode Alpha Cronbarch untuk menguji realibilitas instrumen. Koefisien Alpha Cronbarch antara 0 sampai dengan 1, jika $\alpha<0,6$ maka instrumen dianggap reliable. Rumus yang digunakan adalah [22]:

$R_{11}=\left(-\frac{k}{(k-1)}\right)\left(1-\frac{\sum \sigma b^{2}}{\sigma^{2} t}\right)$

Keterangan :

$\mathrm{R}_{11}=$ Koefisien Reliabilitas. $\quad \sigma^{2} \mathrm{t} \quad=$ Jumlah varian butir.

$\sum \sigma_{\mathrm{b}}^{2}=$ Jumlah varian total. $\quad \mathrm{k} \quad=$ Jumlah butir pertanyaan.

\subsection{Analis Data}

Dalam penelitian ini, peneliti menggunakan metode statistik deskriptif. Dimana statistik deskriptif merupakan statistik yang digunakan untuk menganalisis data dengan cara mendeskripsikan atau menggambarkan data yang telah terkumpul sebagaimana adanya [17]. Skala penilaian yang digunakan dalam penelitian ini adalah skala Likert, dimana skor yang diberikan berskala 1 sampai 5 dengan penjabaran sebagai berikut: 
Tabel 1. Skala Likert, skor jawaban dalam pernyataan.

\begin{tabular}{cccc}
\hline No & Angka & Simbol & Makna Kualitatif \\
\hline 1 & 1 & TP & Tidak pernah diterapkan, Sangat rendah. \\
2 & 2 & PT & Pernah diterapkan, Rendah. \\
3 & 3 & CS & Cukup sering diterapkan, Cukup tinggi. \\
4 & 4 & ST & Sering diterapkan, Tinggi. \\
5 & 5 & SS & Sangat sering diterapkan, Sangat tinggi. \\
\hline
\end{tabular}

Sumber : Sugiyono (2010:2017)[23]

Hasil dari kuesioner yang telah diisi oleh responden akan di gambarkan dalam bentuk prosentase, maka akan didapatkan skor rata-rata tingkat penerapan Keselamatan dan Kesehatan Kerja per indikator dan keseluruhan. Prosentase keseluruhan selanjutnya akan di klasifikasikan menurut tabel 2 untuk mendapatkan tingkat penerapan Keselamatan dan Kesehatan Kerja.

Tabel 2. Klasifikasi Prosentase Tingkat Penerapan K3.

\begin{tabular}{ccc}
\hline No. & Komulatif Persen $(\%)$ & Klasifikasi \\
\hline 1. & $76 \%-100 \%$ & Sangat Baik \\
2. & $51 \%-75 \%$ & Baik \\
3. & $26 \%-50 \%$ & Buruk \\
4. & $0 \%-25 \%$ & Sangat Buruk \\
\hline
\end{tabular}

Sumber :Riduwan(2002) [24].

\section{Hasil dan Diskusi}

\subsection{Uji Validitas}

Uji Validitas Item atau butir pernyataan dilakukan dengan menggunakan software IBM SPSS Statistic 25. Dasar pengambilan Uji Validitas Pearson :

a) Perbandingan Nilai rhitung dengan rtabel

Jika nilai rhitung > rtabel maka instrumen valid, jika nilai rhitung < rtabel maka instrumen tidak valid .Cara mencari nilai rtabel dengan jumlah sampel $(\mathrm{N})=60$,signifikasi $5 \%$ pada distribusi nilai rtabel statistic, maka di peroleh nilai rtabel sebesar 0,254. 
b) Melihat nilai Signifikansi (Sig.)

Jika nilai signifikansi $<0,05$ maka instrumen valid, jika nilai signifikansi $>0,05$ maka instrumen tidak valid.

Hasil perhitungan Uji validitas instrumen yang sudah diolah menggunakan software IBM SPSS Statistic 25 di ringkas dalam bentuk tabel untuk mempermudah dalam memilih pernyataan angket yang valid dan menghilangkan pernyataan yang tidak valid.

Tabel 3. Hasil Pengujian Validitas Instrument.

\begin{tabular}{lcccc}
\hline No Item & Rhitung & rtabel 5\% (60) & Sig. & Kriteria \\
\hline X1.1 & 0,710 & 0,254 & 0,000 & Valid \\
X1.2 & 0,556 & 0,254 & 0,006 & Tidak Valid \\
X1.3 & 0,572 & 0,254 & 0,000 & Valid \\
X2.1 & 0,633 & 0,254 & 0,000 & Valid \\
X2.2 & 0,495 & 0,254 & 0,000 & Valid \\
X2.3 & 0,451 & 0,254 & 0,010 & Tidak Valid \\
X3.1 & 0,762 & 0,254 & 0,000 & Valid \\
X3.2 & 0,634 & 0,254 & 0,000 & Valid \\
X3.3 & 0,711 & 0,254 & 0,000 & Valid \\
X4.1 & 0,640 & 0,254 & 0,000 & Valid \\
X4.2 & 0,818 & 0,254 & 0,000 & Valid \\
X4.3 & 0,475 & 0,254 & 0,000 & Valid \\
X5.1 & 0,531 & 0,254 & 0,000 & Valid \\
X5.2 & 0,593 & 0,254 & 0,000 & Valid \\
X5.3 & 0,592 & 0,254 & 0,000 & Valid \\
\hline
\end{tabular}

Sumber : Analisa Pengolahan Data Pengujian Validasi Instrument.

Berdasarkan hasil uji validitas yang telah disajikan pada tabel 3, di dapatkan 2 pernyataan angket dengan nilai signifikansi > 0,05, yaitu instrumen X1.2 dan X2.3. Sehingga dua pernyataan tersebut dianggap tidak valid. Pernyataan yang tidak valid harus di hilangkan dan tidak diikutsertakan dalam uji realibilitas.

\subsection{Uji Realibilitas}

Hasil uji validitas pernyataan kuesioner yang valid harus di uji reliabilitasnya. Uji reliabilitas menggunakan software IBM SPSS Statistic 25. Nilai hasil pengujian reabilitas dapat dilihat pada Tabel 4. dibawah ini : 
Tabel 4. Hasil Pengujian Reliabilitas Instrument.

Case Processing Summary

\begin{tabular}{llrr} 
& $\mathrm{N}$ & \multicolumn{2}{c}{$\%$} \\
\hline Cases & Valid & 60 & 100,0 \\
& & &, 0 \\
& Excluded $^{\mathrm{a}}$ & 0 & 100,0 \\
& Total & 60 & 100 \\
\end{tabular}

a. Listwise deletion based on all variables in the procedure.

Reliability Statistics

Cronbach's Alpha

$\mathrm{N}$ of Items

802

Sumber : Hasil Output IBM SPSS Statistic 25.

Berdasarkan tabel 4 nilai cronbach's alpha adalah 0,802 karena lebih dari 0,80 sehingga instrumen angket dalam penelitian ini dapat dinyatakan baik atau reliabel.

\subsection{Uji Analis Frekuensi Statistik}

Analisis data yang digunakan dalam penelitian ini adalah data kuesioner dari penelitian yang telah diisi semua responden, yang sudah memenuhi syarat uji validitas dan reliabilitas, dan sudah diketahui frequensi statistic tingkat penerapan Keselamatan dan Kesehatan Kerja. Kemudian dari hasil kuesioner yang sudah diketahui frequensi statistic tersebut akan digunakan untuk menyimpulkan penelitian yang telah dilakukan.

Berdasarkan hasil data tabel uji analisis frekuensi statistik yang hanya di ambil nilai percent (\%) yang paling tinggi dari setiap pernyataan lalu dihitung prosentase rata-rata dari setiap indikator kemudian di masukan dalam bentuk tabel dan grafik agar mempermudahkan untuk mengetahui tingkat penerapan Keselamatan dan Kesehatan Kerja pada proyek pembangunan gedung kuliah bersama kampus C UNAIR Surabaya. Untuk hasil prosentase rata-rata tingkat penerapan K3 dapat dilihat pada Tabel 5. Dibawah ini : 
Tabel 5. Prosentase Rata-Rata Tingkat Penerapan K3.

\begin{tabular}{|c|c|c|c|c|c|}
\hline No. & Pernyataan & Kode & $\begin{array}{c}\text { Skor } \\
\text { Pernyataan }\end{array}$ & $\begin{array}{l}\text { Percent } \\
(\%)\end{array}$ & $\begin{array}{l}\text { Rata- } \\
\text { Rata }\end{array}$ \\
\hline \multirow[t]{3}{*}{$\mathrm{X} 1$} & Publikasi K3 & & & & $70,00 \%$ \\
\hline & $\begin{array}{l}\text { Perusahaan telah melakukan sosialisasi tentang } \\
\text { pentingnya penggunaan Alat Pelindung Diri }\end{array}$ & $\mathrm{X} 1.1$ & ST & $71,70 \%$ & \\
\hline & $\begin{array}{l}\text { Di lingkungan proyek terdapat pesan pesan tentang } \\
\text { keselamatan kerja }\end{array}$ & $\mathrm{X} 1.3$ & SS & $68,30 \%$ & \\
\hline \multirow[t]{3}{*}{$\mathrm{X} 2$} & Produktivitas Pekerja & & & & $77,50 \%$ \\
\hline & $\begin{array}{l}\text { Pekerja mengetahui karakteristik peralatan kerja } \\
\text { yang disediakan oleh perusahaan }\end{array}$ & $\mathrm{X} 2.1$ & SS & $76,70 \%$ & \\
\hline & $\begin{array}{l}\text { Pekerja memahami fungsi peralatan kerja yang } \\
\text { disediakan oleh perusahaan }\end{array}$ & $\mathrm{X} 2.2$ & SS & $78 \%$ & \\
\hline \multirow[t]{4}{*}{$\mathrm{X} 3$} & Peningkatan Kesadaran K3 & & & & $71,67 \%$ \\
\hline & $\begin{array}{l}\text { Perusahaan memberikan perhatian yang besar terhadap } \\
\text { masalah K3 }\end{array}$ & $\mathrm{X} 3.1$ & SS & $73,30 \%$ & \\
\hline & Perusahaan menempatkan K3 sebagai prioritas utama & $\mathrm{X} 3.2$ & SS & $70,00 \%$ & \\
\hline & $\begin{array}{l}\text { Perusahaan sangat memperhatikan Keselamatan dan } \\
\text { Kesehatan Kerja karyawan }\end{array}$ & $\mathrm{X} 3.3$ & SS & $71,70 \%$ & \\
\hline \multirow[t]{4}{*}{$\mathrm{X} 4$} & Kontrol Lingkungan Kerja & & & & $88,90 \%$ \\
\hline & $\begin{array}{l}\text { Pengecekan kondisi APD dan penyediaan APD yang } \\
\text { lengkap secara berkala }\end{array}$ & $\mathrm{X} 4.1$ & SS & $91,70 \%$ & \\
\hline & Perusahaan menyediakan P3K & $\mathrm{X} 4.2$ & SS & $85,00 \%$ & \\
\hline & $\begin{array}{l}\text { Perbaikan/mengganti peralatan kerja yang menimbulkan } \\
\text { bahaya jika teridentifikasi memiliki potensi bahaya }\end{array}$ & $\mathrm{X} 4.3$ & SS & $90,00 \%$ & \\
\hline \multirow[t]{4}{*}{$\mathrm{X} 5$} & Pengawasan dan Disiplin & & & & $81,13 \%$ \\
\hline & Kewajiban penggunaan APD & X5.1 & SS & $80,00 \%$ & \\
\hline & $\begin{array}{l}\text { Pengecekan terlebih dahulu alat-alat berat yang } \\
\text { berpotensi bahaya sebelum digunakan }\end{array}$ & $\mathrm{X} 5.2$ & SS & $81,70 \%$ & \\
\hline & $\begin{array}{l}\text { Memberikan pengawasan terhadap pekerjaan yang } \\
\text { berpotensi bahaya }\end{array}$ & X5.3 & SS & $81,70 \%$ & \\
\hline
\end{tabular}

Sumber : Analisa Pengolahan Data Prosentase Rata-Rata Tingkat Penerapan K3.

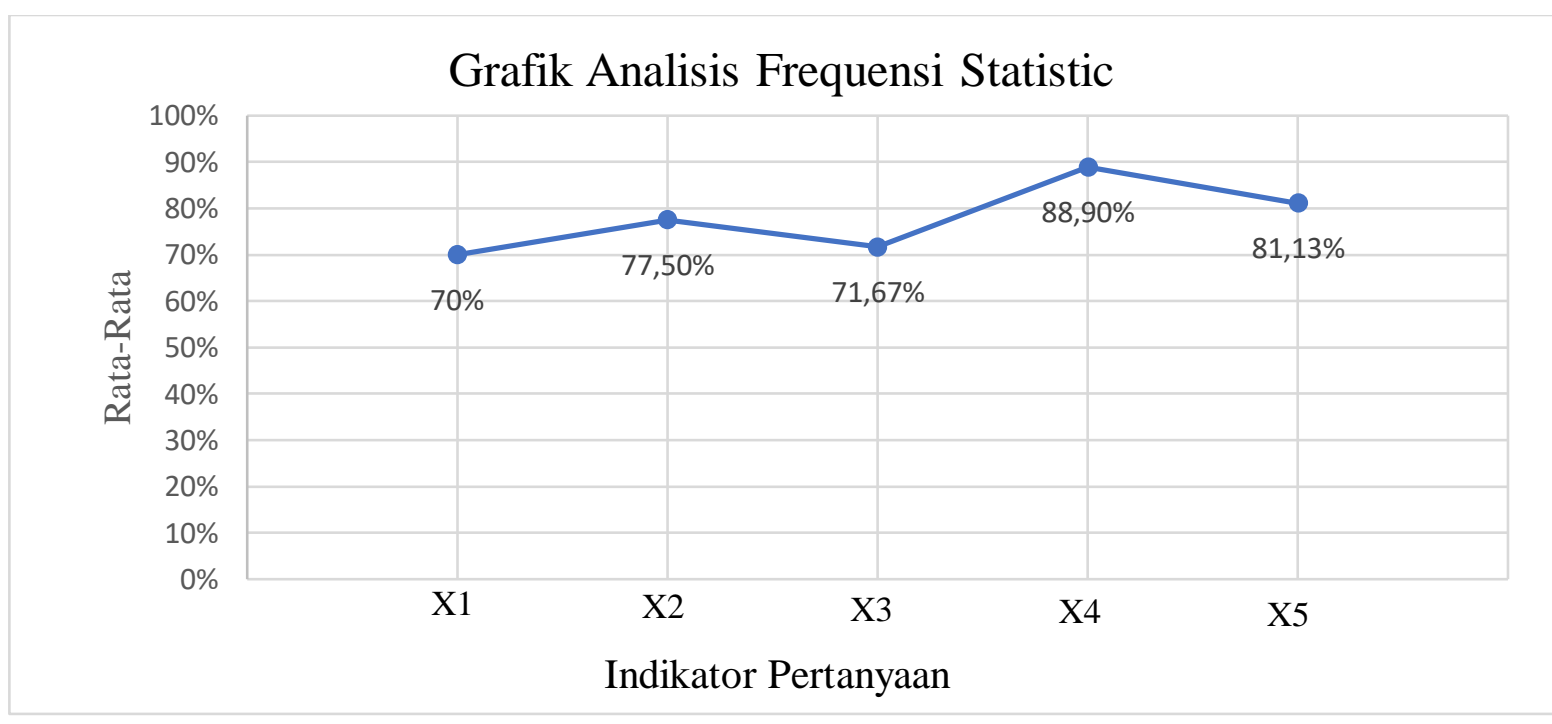

Sumber $\quad$ : Analisa Pengolahan Data Prosentase Rata-Rata Tingkat Penerapan K3.

Gambar 1. Grafik Analisis Frekuensi Statistik.

Dari tabel dan grafik Analisis Frekuensi Statistik diatas, dapat disimpulkan bahwa tingkat penerapan rata-rata tertinggi per indikator adalah Kontrol Lingkungan Kerja dengan 
nilai 88,90\%, dan rata-rata tertinggi per item kuesioner adalah Pengecekan Kondisi APD dan Penyediaan APD yang lengkap secara berkala dengan nilai 91,70\%.

Tabel 6. Hasil klasifikasi Prosentase Tingkat Penerapan K3.

\begin{tabular}{lcccc}
\hline No. & Indikator & Percent $(\%)$ & Rata-Rata & Klasifikasi \\
\hline X.1 & Publikasi K3 & $70,00 \%$ & $77,84 \%$ & Sangat Baik \\
X.2 & Produktivitas Pekerja & $77,50 \%$ & & \\
X.3 & Peningkatan Kesadaran K3 & $71,60 \%$ & & \\
X.4 & Kontrol Lingkungan Kerja & $88,90 \%$ & & \\
X.5 & Pengawasan dan Disiplin & $81,13 \%$ & & \\
\hline Sumber & $: \quad$ Analisa Pengolahan Data Klasifikasi Prosentase Tingkat Penerapan K3.
\end{tabular}

Jadi, nilai prosentase rata-rata tingkat penerapan $\mathrm{K} 3$ pada proyek pembangunan Gedung Kuliah Bersama Kampus C UNAIR Surabaya adalah sebesar 77,84 \% dan masuk dalam kategori sangat baik.

\section{Kesimpulan dan Saran}

\subsection{Kesimpulan}

Berdasarkan hasil penelitian pada proyek pembangunan Gedung Kuliah Bersama Kampus C UNAIR Surabaya dapat di ambil kesimpulan sebagai berikut:

1. Tindakan penerapan Keselamatan dan Kesehatan Kerja (K3) yang dilaksanakan diantaranya:

A. Publikasi K3 dengan prosentase tingkat penerapan rata-rata $70 \%$ yang diperoleh dari pernyataan:

1) Perusahaan telah melakukan sosialisasi tentang pentingnya penggunaan Alat Pelindung Diri dengan prosentase penerapan 71,70\%.

2) Di lingkungan proyek terdapat pesan pesan tentang keselamatan kerja dengan prosentase penerapan $68,30 \%$.

B. Produktivitas Pekerja dengan prosentase tingkat penerapan rata-rata $77,50 \%$ yang diperoleh dari pernyataan:

1) Pekerja mengetahui karakteristik peralatan kerja yang disediakan oleh perusahaan dengan prosentase penerapan $76,70 \%$.

2) Pekerja memahami fungsi peralatan kerja yang disediakan oleh perusahaan dengan prosentase penerapan $78 \%$.

C. Peningkatan kesadaran K3 dengan prosentase tingkat penerapan rata-rata $71,67 \%$ yang diperoleh dari pernyataan: 
1) Perusahaan memberikan perhatian yang besar terhadap masalah $K 3$ dengan prosentase penerapan $73,30 \%$.

2) Perusahaan menempatkan $\mathrm{K} 3$ sebagai prioritas utama dengan prosentase penerapan $70 \%$.

3) Perusahaan sangat memperhatikan Keselamatan dan Kesehatan Kerja karyawan dengan prosentase penerapan $71,70 \%$.

D. Kontrol Lingkungan Kerja dengan prosentase tingkat penerapan rata-rata $88,90 \%$ yang diperoleh dari pernyataan:

1) Pengecekan kondisi APD dan penyediaan APD yang lengkap secara berkala dengan prosentase penerapan $91,70 \%$.

2) Perusahaan menyediakan P3K dengan prosentase penerapan $85 \%$.

3) Perbaikan/mengganti peralatan kerja yang menimbulkan bahaya jika teridentifikasi memiliki potensi bahaya dengan prosentase penerapan $90 \%$.

E. Pengawasan dan Disiplin dengan prosentase tingkat penerapan rata-rata $81,13 \%$ yang diperoleh dari pernyataan:

1) Kewajiban penggunaan APD dengan prosentase penerapan $80 \%$.

2) Pengecekan terlebih dahulu alat-alat berat yang berpotensi bahaya sebelum digunakan dengan prosentase penerapan $81,70 \%$.

3) Memberikan pengawasan terhadap pekerjaan yang berpotensi bahaya dengan prosentase penerapan $81,70 \%$.

2. Tingkat penerapan Keselamatan dan Kesehatan Kerja (K3) memiliki prosentase $77,84 \%$, sehingga dapat di klasifikasikan dalam kategori SANGAT BAIK.

\subsection{Saran}

Berdasarkan hasil penelitian, saran yang dapat disampaikan adalah pelaksanaan Keselamatan dan Kesehatan Kerja (K3) di lapangan harus benar-benar diperhatikan serta diterapkan sesuai prosedur supaya pekerjaan dapat berjalan dengan efektif dan pemahaman pekerja mengenai prosedur penerapan Keselamatan dan Kesehatan Kerja (K3) sangat penting untuk diperhatikan, mengingat hal itu berkaitan langsung dengan kinerja karyawan dan dapat meminimalisir terjadinya kecelakaan kerja. Penelitian selanjutnya disarankan untuk menambahkan solusi yang bisa dilakukan apabila penerapan K3 belum dilaksanakan dengan baik. 


\section{Daftar Pustaka}

[1] P. N. Sarlinton, R. Pratiwi, and Syahruddin, "Identifikasi Penerapan K3 Pada Gedung Pemerintah,” J. Mahasiwa Tek. Sipil Univ. Tanjungpura, vol. 5, no. 2, 2018.

[2] Brandi Karasiewicz Alford, S. Lynch, I. Rosenblum, and C. Kullmann, “Occupational Health and Safety Guidebook," Int. Comm. Occup. Heal., 2017.

[3] E. Swaputri, “Analisis Penyebab Kecelakaan Kerja (Studi Kasus di PT. Jamu Air Mancur)," Ilmu Kesehat. Masy. Fak. Ilmu Keolahragaan Univ. Negeri Semarang, 2009.

[4] E. al. Choudhry, R.M., "Journal of Safety Management in Construction: Based Practices in Hongkong," ASCE Libr., vol. 134, no. 1, 2008.

[5] V. Mintje, G. Y. Malingkas, D. R. O. Walangitan, and H. Tarore, "Penerapan Sistem Pengendalian Keselamatan Dan Kesehatan Kerja Pada Pelaksanaan Konstruksi (Studi Kasus: Lanjutan Pembangunan Fasilitas Pelabuhan Laut Manado Ta 2012),” J. Sipil Statik, vol. 1, no. 9, pp. 616-622, 2013.

[6] International Standards Organization, Occupational Health and Safety Management System-Requirement. BSI American, 2018.

[7] Presiden RI, "UU No. 1 Tahun 1970 Tentang Keselamatan Kerja,” Pemerintah RI, 1970.

[8] M. Lesch, "Comprehension and Memory For Warning Symbols: Age Related Differences and Impact of Training,” J. Safety Res., vol. 34, pp. 495-505, 2003.

[9] Y. Kurniawan, "Tingkat pelaksanaan sistem manajemen keselamatan dan kesehatan kerja (smk3) pada proyek konstruksi, studi kasus di kota semarang," Dr. Diss. Univ. Negara Semarang, vol. 4, no. 1, 2015.

[10] D. F. Choudry, Rafiq.M ., "Why Operatives Engange in Unsafe Work Behavior: Investigating Factors on Construction Sites," Saf. Sci., vol. 46, pp. 566-584, 2008.

[11] I. H. Purwantomo and Solehan, "Analisa Bahaya Keselamatan Dan Kesehatan Kerja ( K3 ) Pada Proyek Konstruksi Bangunan Geduung Kecamatan Gajah Mungkur Semarang," Repos. USM, 2019.

[12] A.- Indah, "Evaluasi Penerapan Keselamatan Dan Kesehatan Kerja (K3) Pada Proyek Bangunan Gedung Di Kabupaten Cirebon,” J. Tek. Sipil dan Perenc., vol. 19, no. 1, pp. 1-8, 2017, doi: 10.15294/jtsp.v19i1.9492.

[13] B. Derviş, "Journal of Chemical Information and Modeling," J. Chem. Inf. Model., vol. 53, no. 9, pp. 1689-1699, 2013, doi: 10.1017/CBO9781107415324.004. 
[14] E. Kurniawati, "KESELAMATAN DAN KESEHATAN KERJA (K3) PADA PROYEK KONSTRUKSI DI KOTA BANDUNG," e-Journal UAJY, 2018, doi: 10.1093/imamci/dnt037.

[15] D. Yulistyorini, "Pengaruh Penerapan Sistem Manajemen Keselamatan Kerja (SMK3) Terhadap Tingkat Kecelakaan Kerja Pada Proyek Konstruksi Di Kota Malang,” Dr. Diss. UM, 2018.

[16] D. S. Eka Saputra, "PENGARUH KESELAMATAN DAN KESEHATAN KERJA TERHADAP KINERJA PEKERJA PROYEK KONSTRUKSI SAMASTA MOEVENPICK HOTEL DAN RESORT JIMBARAN BALI (PT.TATA MULIA NUSANTARA),"Repos. Unej, 2016.

[17] A. Feriyanto, "Identifikasi Resiko Keselamatan dan Kesehatan Kerja Pada Proyek Pembangunan Gedung Kuliah Universitas Muhammadiyah Gresik," SKRIPSI Jur. Tek. Sipil-Fakultas Tek. UM, 2016.

[18] \& M. K. Z. Elphiana E.G, Yuliansyah M. Diah, "Pengaruh Keselamatan Dan Kesehatan Kerja Terhadap Kinerja Karyawan Pt. Pertamina Ep Asset 2 Prabumulih,” JEMBATANB- J. Ilm. Manaj. Bisnis Dan Terap., no. 2, pp. 103-118, 2017.

[19] W. Y. Christina, L. Djakfar, and A. Thoyib, "Pengaruh Budaya Keselamatan dan Kesehatan Kerja (K3) terhadap kinerja proyek konstruksi," Rekayasa Sipil, vol. 6, no. 1, pp. 83-95, 2012.

[20] A. E. Milen, "Analisis Level Keselamatan Dan Kesehatan Kerja ( K3 ) Proyek Konstruksi Terhadap Risiko Dan Manajemen K3," Fak. Tek. Univ. Lampung, vol. 3, 2016.

[21] R. N. Bulannurdin and Sugiyarto, "Analisis Pengaruh Keselamatan Dan Kesehatan Kerja (K3) Terhadap Kinerja Pekerja Konstruksi (Studi Kasus Proyek Pembangunan the Park Solo Baru)," Matriks Tek. Sipil, vol. 1, no. 2, pp. 54-61, 2013.

[22] B. Derviş, "KESELAMATAN DAN KESEHATAN KERJA," J. Chem. Inf. Model., vol. 53, no. 9, pp. 1689-1699, 2016, doi: 10.1017/CBO9781107415324.004.

[23] Zakky, Pengertian Instrumen Penelitian Menurut Para Ahli (Arikunto, Sugiyono, dkk). Zona Referensi, 2018.

[24] Riduwan and Warsiman, "Skala Pengukuran Variabel-Variabel Penelitian," Alfabeta, 2008. 